\title{
Research
}

\section{Livestock Subsidies and Rangeland Degradation in Central Crete}

\author{
$\underline{\text { Hugues Lorent }}^{1}, \underline{\text { Ruth Sonnenschein }}^{2}, \underline{\text { Georgios M. Tsiourlis }}^{3}$ Patrick Hostert $^{2}$, and Eric Lambin $^{1}$
}

\begin{abstract}
Marginal and unstable environmental conditions force stockbreeders in drylands to develop adaptive strategies to ensure stability of production. In intensive market-oriented pastoral systems, the partial substitution of rangeland forage production by external feed increases the influence of commodity prices in stockbreeders' decisions, which become increasingly decoupled from environmental constraints. In Mediterranean countries of the European Union (EU), Common Agricultural Policy (CAP) subsidies also influence agricultural practices, potentially increasing environmental impacts. By modeling subsidy allocation to sheep and goat breeders in Crete, we showed that livestock subsidies for Less Favoured Areas (LFA) stimulated flock growth up to a point. By linking interviews of farmers to remote-sensing data in four village communities in central Crete, we tested statistically alternative hypotheses explaining the links between CAP subsidies, livestock-husbandry practices, and land degradation at the farm level. The flock growth stimulated by livestock subsidies was accompanied by the intensification of herd management, and decreasing yields and profits, with no statistical association to vegetation degradation. Farms with larger flocks became more sensitive to market fluctuations.
\end{abstract}

Key Words: Common Agricultural Policy; Crete; desertification; sheep and goats; subsidies; vegetationcover trend

\section{INTRODUCTION}

Human populations living in drylands often depend on livestock for consumption and as a source of income. Therefore, these communities are particularly reliant on the primary production of rangelands. This, in turn, depends on rainfall, however irregular (Gillson and Hoffmann 2007). As rangeland feed production can be uncertain, stockbreeders in drylands implement adaptive strategies to better cope with drought and preserve rangeland productive functions (Turner et al. 2005, Berzborn 2007). These include traditional practices such as ensuring herd mobility, market destocking (Turner and Williams 2002), or reliance on commercially produced feed. In highly intensified livestock systems where stock feeding mainly depends on dietary supplements purchased offfarm, commodity prices may become key drivers for stockbreeders' decisions, as market fluctuations impact the profitability of their land-use practices. Important changes in commodity prices over short periods may lead farmers to make decisions about production without evaluating their environmental consequences (Boardman et al. 2003). It has been stated that periods of favorable market conditions may encourage higher stocking rates, whereas immediate destocking does not necessarily follow unforeseen declines in commodity prices. This may result in financial losses for stockbreeders who keep far more animals than forage can support, expecting better prices to avoid restocking costs (Stafford Smith et al. 2007).

Overgrazing by sheep and goats is a major contributing factor to land degradation in southern Europe (Papanastasis 1998, Thornes 1990) and has been widely reported on the Greek island of Crete. The Common Agricultural Policy (CAP) subsidies of the European Union (EU) have been pointed to as a potential driver of livestock growth and consequent increased grazing pressure that has led to land degradation in Greece (Lyrintzis 1996, Juntti and Wilson 2005).

\footnotetext{
${ }^{1}$ University of Louvain, ${ }^{2}$ Humboldt-Universität zu Berlin, ${ }^{3}$ National Agricultural Research Foundation (NAGREF)
} 
The objectives of our work were to analyze how CAP subsidies have affected the practices of sheep and goat husbandry units, and to examine how husbandry practices have influenced land degradation in the mountainous areas of central Crete over the last decade, just before the implementation of the latest CAP reform in 2006. We studied four mountain village communities in central Crete. We used vegetation-cover change information extracted from remote-sensing data as an indicator of biophysical land degradation (Hostert et al. 2003, Roder et al. 2008). Two approaches were used to investigate the links between land degradation and the impact of CAP subsidies on farm production. First, we modeled the conditions under which specific CAP payments for sheep and goat husbandry were allocated and analyzed their potential influence on land-use decision making and their related environmental impacts. Second, we linked household-interview data to vegetation-cover change data (Rindfuss et al. 2003, Lorent et al. 2008). Two alternative hypotheses on the influence of CAP subsidies on stock breeding were tested. (1) The "intensification hypothesis" questions whether subsidies create an incentive for stockbreeders to intensify livestock feeding and thus decrease grazing pressure on their rangelands. (2) The "flock-growth hypothesis" questions whether subsidies lead to an increase in stock numbers, therefore causing overgrazing. We tested each hypothesis with multivariate linear regressions. The influence of flock growth and intensification on production and profitability was also tested to evaluate the indirect impact of subsidies on farm income. Finally, we analyzed the evolution of prices of agricultural input and output for recent years to assess the impact of market stressors on the wealth of small stock holdings.

\section{Rangelands of Central Crete}

Crete has been inhabited since Neolithic times, and its landscape has been deeply transformed by humans (Lyrintzis 1996). The population of the island is approximately 600000 . Agriculture contributes up to $13 \%$ of the island's Gross Domestic Product (GDP) and employs 6.7\% of the workforce. Economically, olive oil is Crete's most important agricultural product (Tsakiris et al. 2007). The climate is Mediterranean, ranging from subhumid to semiarid. On average, rainfall has decreased over the last two decades. The dry season extends from March-November. Winter is characterized by highly variable rainfall and long wet spells, although these are decreasing in length (Hatzianastassiou et al. 2007, Tolika and Maheras 2004). Precipitation also varies strongly with elevation (Naoum and Tsanis 2003). Southern and eastern Crete are drier and more prone to drought (Tsakiris 2007). The dominant land use is rangeland, occupying nearly half of the island and extending from sea level up to $2500 \mathrm{~m}$ (Menjli and Papanastasis 1995). The total area of rangeland has remained stable during the last two decades. Deforestation, extensive grazing, and humaninduced fires on the island over centuries have caused the native evergreen woodlands to be replaced by shrub-degradation formations. Phrygana, a xeromorphic type of vegetation typical of intensively grazed areas, dominates rangelands and is found at all altitudes (Kyriakakis and Papanastasis 1997, Tsiourlis et al. 2001).

When Greece joined the European Economic Community (EEC) in 1981, many long-established conservation practices were abandoned for more intensive practices (Lyrintzis 1996). Specifically, increasing sheep and goat husbandry in poor rangeland conditions relies on the use of concentrated fodder. The consequences of overgrazing on land degradation in central Crete are diverse, including a decrease in biodiversity, a decrease in vegetation cover, and increased soil erosion (Boix et al. 1995, Cerda 1998, Tsiourlis and Konstantinidis 2006). Complex land-tenure systems and communal grazing arrangements are also reported to be causes of poor range condition and low productivity (Papanastasis 1993).

The sheep and goat breeding sectors in Crete are characterized by a relatively small and decreasing workforce intensity, and the use of large areas of rangeland (Eurostat 2008a). Between 1981-1995, the number of sheep and goats in Crete doubled (Lyrintzis 1996). Between 1990-2005, animal numbers kept growing but, at the same time, the number of holdings with small ruminants decreased, i.e., the average number of animals per enterprise increased (Eurostat 2008 $a, b$ ). In 2005, the average agricultural area of small stock enterprises was 43.5 ha, an increase of 8 ha from 2000 . Fodder crops were grown more often than cereals by Cretan stockbreeders, with 5.29 ha/holding on average in 2005 and only 0.83 ha/holding for cereals (Eurostat $2008 b)$. 
Figure 1. Studied village communities, household grazing areas and pixel-based vegetation-cover trend.

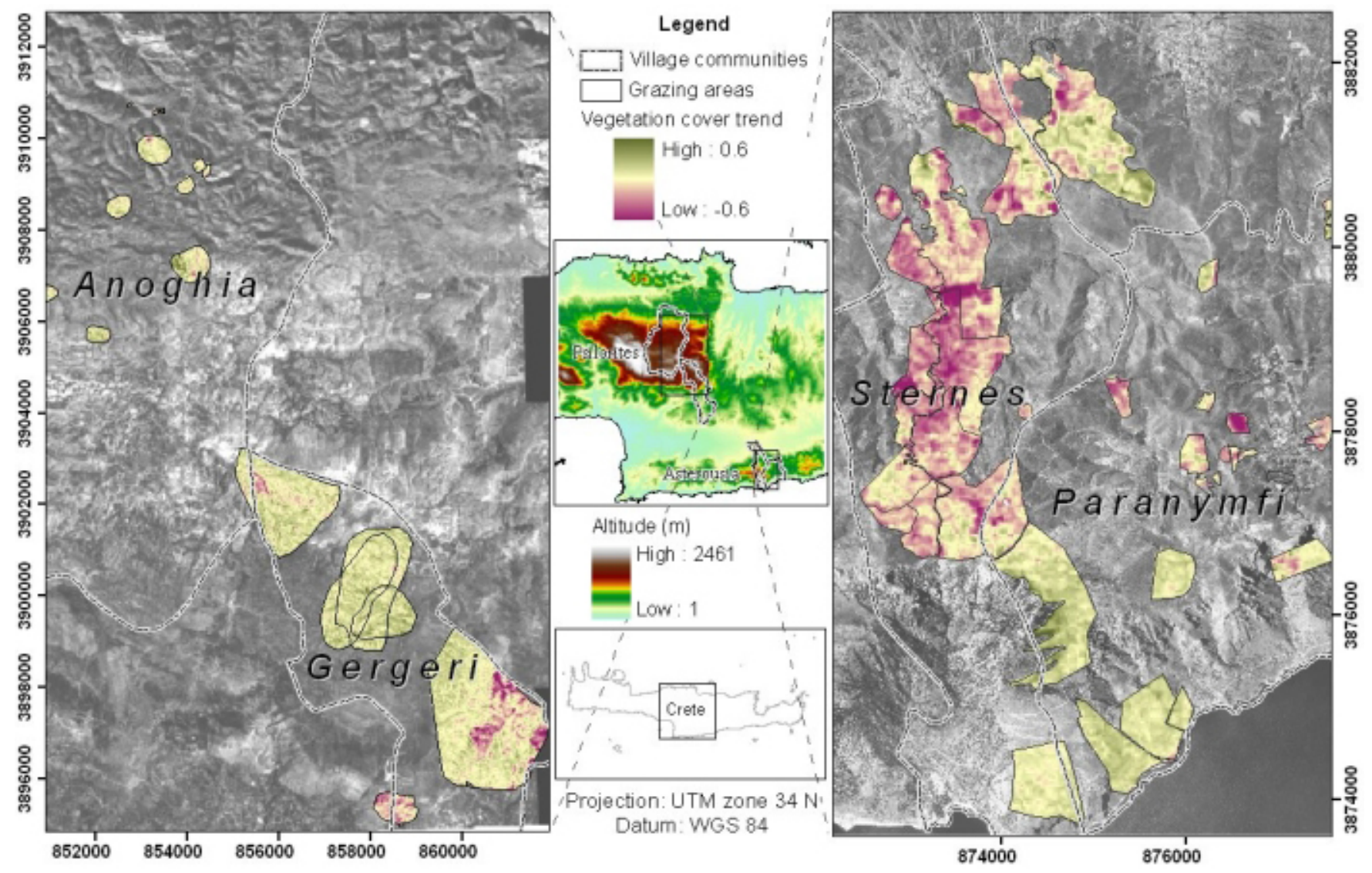

\section{Study Area}

The center of the island is crossed by two mountain ranges, the Asterousia and the Psilorites (Fig. 1), reaching $1207 \mathrm{~m}$ and $2476 \mathrm{~m}$, respectively. The geological substrate of the Asterousia is flysch on its northern slopes, and limestone on the steeper southern side. Precipitation ranges from 400-800 $\mathrm{mm} / \mathrm{yr}$. The main land cover is rangeland, sparsely covered by phrygana. It is primarily used as a grazing area, interspersed with plots of olive trees, vines, and meadows. There are some signs of soil erosion (Hill et al. 1998). Few remains of climax vegetation are found (Tsiourlis and Konstantinidis 2006). The Psilorites are the highest mountain range in Crete. The bedrock is limestone, with some flysch in the foothills. Mean annual precipitation is up to $1000 \mathrm{~mm}$, with extensive snowfalls above $1200 \mathrm{~m}$. In the Mediterranean zone of the Psilorites (200$800 \mathrm{~m}$ ), phrygana and medium-height matorrals are found, with a few stands of Pinus brutia and sparse forests of Quercus coccifera on the southern slopes. Upper altitudes are covered by spiny formations of shrubs called orophrygana (Tsiourlis et al. 2001). All types of vegetation formations in the two mountain chains are grazed throughout the year (Papanastasis and Misbah 1998), although transhumance is still practiced by some farmers in the Psilorites.

We focused on four village communities located in the Asterousia and the Psilorites (Fig. 1, Table 1). 
Table 1. Biophysical attributes of the surveyed municipalities.

\begin{tabular}{|c|c|c|c|c|c|c|c|}
\hline $\begin{array}{l}\text { Municipa- } \\
\text { lity }\end{array}$ & $\begin{array}{l}\text { Village } \\
\text { community }\end{array}$ & $\begin{array}{l}\text { Main climatic } \\
\text { zones of } \\
\text { rangeland areas }\end{array}$ & $\begin{array}{l}\text { Altitudinal } \\
\text { range (m } \\
\text { ASL) }\end{array}$ & Geological substrates & $\begin{array}{c}\text { Annual } \\
\text { average } \\
\text { precipitation } \\
(\mathrm{mm})\end{array}$ & $\begin{array}{l}\text { Total area } \\
\text { (ha) }\end{array}$ & $\begin{array}{l}\text { Rangeland } \\
\text { area (ha)* }\end{array}$ \\
\hline Anoghia & Anoghia & $\begin{array}{l}\text { Oro- } \\
\text { Mediterranean }\end{array}$ & $414-2163$ & Massive carbonates & 1100 & 10267 & 9228 \\
\hline Rouva & Gergeri & $\begin{array}{l}\text { Eu- } \\
\text { Mediterranean/ } \\
\text { Oro- } \\
\text { Mediterranean }\end{array}$ & $202-1854$ & $\begin{array}{l}\text { Massive carbonates, } \\
\text { some flysch }\end{array}$ & 900 & 4447 & 2654 \\
\hline Asterousia & Paranymfi & $\begin{array}{l}\text { Eu- } \\
\text { Mediterranean/ } \\
\text { Oro- } \\
\text { Mediterranean }\end{array}$ & $0-1118$ & $\begin{array}{l}\text { Massive carbonates, } \\
\text { flysch }\end{array}$ & 450 & 2178 & 2002 \\
\hline Kofina & Sternes & $\begin{array}{l}\text { Thermo- } \\
\text { Mediterranean/ } \\
\text { Eu- } \\
\text { Mediterranean }\end{array}$ & $0-1200$ & $\begin{array}{l}\text { Flysch, massive } \\
\text { carbonates }\end{array}$ & 500 & 2057 & 1541 \\
\hline
\end{tabular}

*Rangeland areas were extracted from the CORINE land-cover spatial database

Their populations were of different sizes, and have fluctuated differently over the last $60 \mathrm{yrs}$, decreasing since the 1960s in Asterousia and since the 1980s in Gergeri in the Psilorites (Table 2). The evolution of sheep and goat farms and of livestock numbers between 1981-2000 is shown in Fig. 2. Socioeconomic characteristics of farms in the four village communities in 2000 are summarized in Table 3.

\section{METHODS}

\section{Data}

\section{Time series of remote-sensing imagery}

We used a time series of 14 Landsat Thematic Mapper and Enhanced Thematic Mapper+ images between 1984-2005. Each image was taken between mid-May and mid-June when rangeland vegetation is at its maximum development.

\section{Household survey}

We interviewed 39 stock-breeding household representatives during a field survey in April-May 2007 using a formal questionnaire. The individual interviews were carried out in four mountain village communities (Fig. 1, Table 1). We collected information about flocks, production costs, crops, and dairy production for 2005, just before the implementation of the 2003 CAP reforms in Greece. Respondents drew the spatial extent of their grazing areas on recent aerial orthophotos. We digitized rangeland extent and georeferenced household socioeconomic data. These were then integrated in a geodatabase to link agricultural household data with land-cover changes derived from remotesensing images. As we could not quantify errors for socioeconomic and rangeland extent data, we defined a quality index based on the interviewer's perception of the reliability of interviewees' answers, crosschecks in the questionnaires, and spatial match among grazing areas drawn and other spatial data such as land-use maps. Against the 
Table 2. Decadal population censuses (inhabitants) in the four village communities (1951-2001).

\begin{tabular}{lrrrrrr}
\hline \hline & 1951 & 1961 & 1971 & 1981 & 1991 & 2001 \\
\hline Gergeri & 1521 & 1508 & 1590 & 1746 & 1683 & 1506 \\
Paranymfi & 251 & 285 & 260 & 247 & 237 & 213 \\
Sternes & 517 & 582 & 510 & 447 & 415 & 396 \\
Anogia & 2581 & 2461 & 2750 & 2449 & 2223 & 2454 \\
& & & & & & \\
\hline
\end{tabular}

background of this plausibility check, we kept 33 questionnaires out of 39 for analysis. This included eight in Anoghia, nine in Gergeri, seven in Paranymfi, and nine in Sternes.

\section{Local and national socioeconomic data}

Time series of input and output prices for livestock husbandry in Crete and Greece were obtained from Eurostat (2008a) and from the National Statistical Service of Greece(NSSG 2009). The Farm Accountancy Data Network (FADN) database (European Commission 2008b) was used to analyze the evolution of the agricultural income of farmers specialized in small ruminants in Crete over the last two decades. We also used local agricultural indices for 2005 (District of Crete 2006) and national decennial livestock censuses.

\section{Approach}

Below, we first describe how land degradation was measured. We then explain the methods used to analyze the allocation of subsidies and their links with land degradation and farm production. Finally, we describe how the impact of distant macroeconomic factors on farm return was assessed.

\section{Vegetation cover and trends}

We analyzed vegetation-cover change from a time series of Landsat images. After geometric, atmospheric, and topographic corrections, we used spectral-mixture analysis based on a spectral- endmember library to extract vegetation-cover values for each image. We computed the trend of vegetation cover at the pixel level by linear regression. We produced maps of average vegetation-cover trend and mean vegetation cover for the period under consideration (Hostert et al. 2003, Sonnenschein 2008). We then extracted mean vegetation cover and vegetation-cover trend values for each village community and household/farm $(\mathrm{HH} / \mathrm{F})$ by overlaying their respective vectorized rangeland areas with the corresponding vegetation maps (Fig. 1). We used these average values as biophysical indicators for vegetation state and change at the village community and farm levels. We considered trend values $<-5 \%$ as negative, $>5 \%$ as positive, and intermediate values as neutral, according to Hostert et al. (2003).

We ran a $t$-test and linear regressions to evaluate the influence of geology, slope, and altitude on vegetation-cover trend, derived from a geological map and a 20-m digital elevation model. We used an iterative procedure to produce a pseudorandom sample of 150 pixels in rangeland areas of the surveyed households. The spacing between samples was defined to minimize the spatial autocorrelation of vegetation-cover trend. Mean vegetation cover and vegetation-cover trend values for each sample pixel were classified according to the bedrock and related to their elevation and slope.

\section{Subsidies-allocation model}

Based on information collected at the agricultural service of Thessaloniki, we modeled the two main subsidies for sheep and goat breeders, namely the 
Figure 2. Sheep and goat farms and flock size in the four surveyed municipalities according to the Greek agricultural censuses of 1981, 1991, and 2000 (data about sheep holdings for 2000 are missing for Sternes).
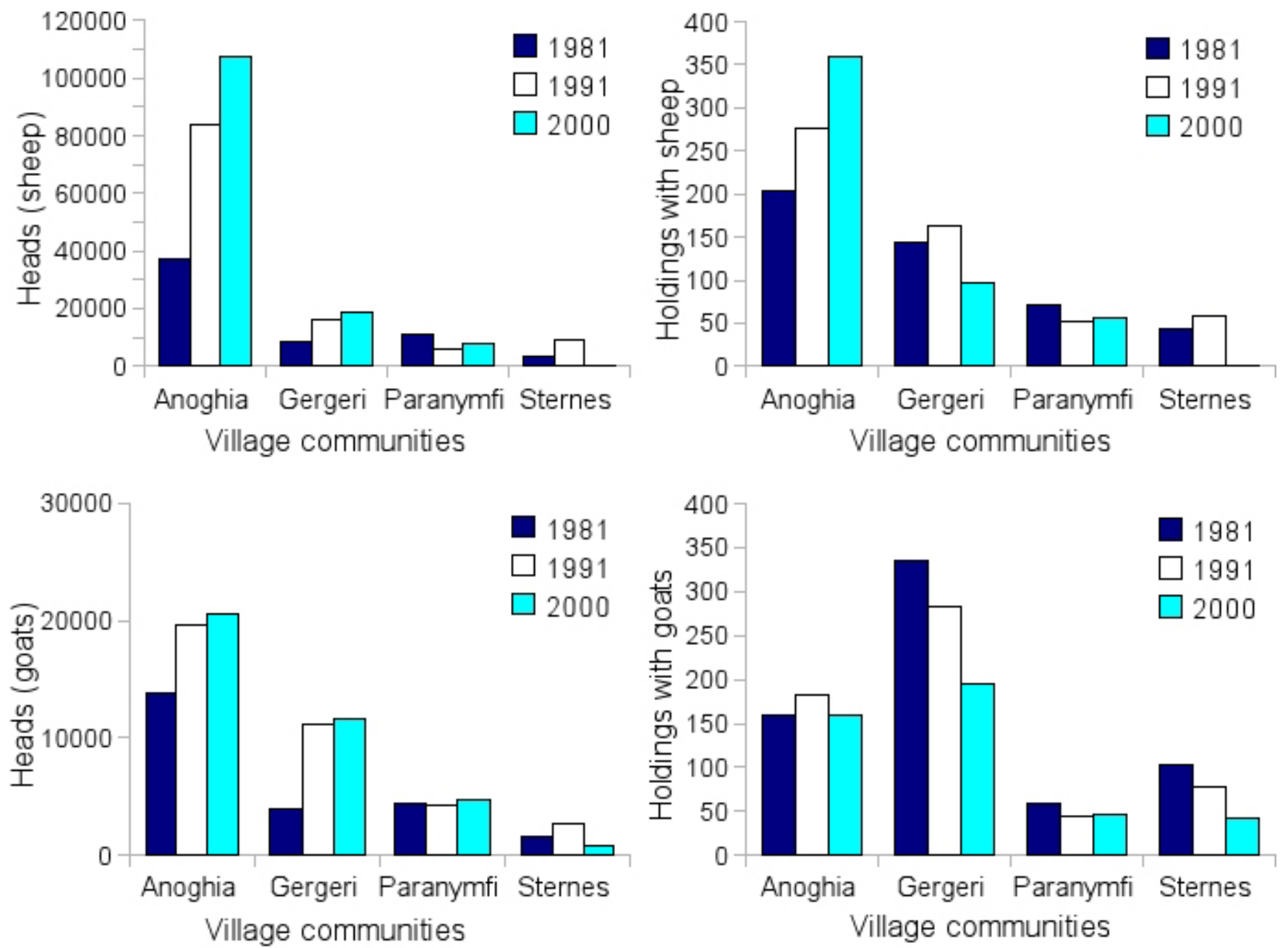

"ewe premium" (European Council [EC] Regulation 2529/2001) and "Less Favoured Area" (LFA) compensation subsidies (Council Regulation 1257/99). The calculation of the LFA subsidy is divided into two parts, linked to cereal crops and livestock (Fig. 3). Input data include areas of rangeland, fodder, and nonfodder cereal crops, and the number of grazing animals in livestock units $(\mathrm{LU} ; 1$ sheep or goat $=0.15 \mathrm{LU})$. The LFA subsidy has a maximum value of $€ 5000$ per $\mathrm{HH} / \mathrm{F}$. Although for farmers, the ewe premium grows proportionally with flock size, the LFA subsidy is tied to grazing pressure. The total LU must be inferior to the sum of rangeland and fodder areas (in ha). If this limit is exceeded, a penalty of $20 \%$ is applied to the livestock component of the subsidy (Figs. 3, 4). The maximum number of subsidized LU is 50, whereas declarable cereal areas are limited to $15 \mathrm{ha}$ /holding. 
Table 3. Socioeconomic characteristics, land tenure, and household composition of farms from the four village communities in 2000 (GNSS).

\begin{tabular}{|c|c|c|c|c|c|}
\hline Farm characteristics & & $\begin{array}{l}\text { Anog- } \\
\text { hia }\end{array}$ & Gergeri & Paranymfi & Sternes \\
\hline Number of farms & & 615 & 659 & 68 & 111 \\
\hline UAA (ha) & & 8739.35 & 3483.7 & 1432.3 & 562.77 \\
\hline \multirow[t]{3}{*}{ Commercial status of the holding } & $\begin{array}{l}\text { Declared under the name of the stock } \\
\text { breeders }(\%)\end{array}$ & 100 & 100 & 100 & 100 \\
\hline & Companies $(\%)$ & 0 & 0 & 0 & 0 \\
\hline & Mainly market oriented & 72.0 & 82.0 & 100.0 & 97.0 \\
\hline \multirow[t]{4}{*}{ Land tenure } & UAA in ownership (\%) & 83.3 & 58.7 & 100.0 & 99.8 \\
\hline & UAA rented $(\%)$ & 16.2 & 39.7 & 0.0 & 0.2 \\
\hline & UAA owned jointly (\%) & 0.1 & 1.0 & 0.0 & 0.0 \\
\hline & Other land tenure $(\%)$ & 0.5 & 0.6 & 0.0 & 0.0 \\
\hline \multirow[t]{3}{*}{ Farm manager's education level } & Practical learning & 608 & 609 & 67 & 94 \\
\hline & Basic agricultural instruction & 7 & 50 & 1 & 17 \\
\hline & Complete agricultural instruction & 0 & 0 & 0 & 0 \\
\hline $\begin{array}{l}\text { Farms holding accountancy records } \\
(\%)\end{array}$ & & 0 & 8 & 3 & 0 \\
\hline Total farm household members & & 1137 & 1098 & 107 & 221 \\
\hline \multirow[t]{6}{*}{ Household members working on farm } & & 522 & 430 & 39 & 110 \\
\hline & Spouse & 258 & 392 & 37 & 74 \\
\hline & Unmarried children & 224 & 34 & 2 & 31 \\
\hline & Married children & 0 & 3 & 0 & 5 \\
\hline & Parents & 14 & 0 & 0 & 0 \\
\hline & Grandchildren & 26 & 0 & 0 & 0 \\
\hline Non-family workforce & & 0 & 0 & 0 & 0 \\
\hline
\end{tabular}


Figure 3. Less Favoured Area (LFA) subsidy model using a Unified Modeling Language (UML) Activity diagram.

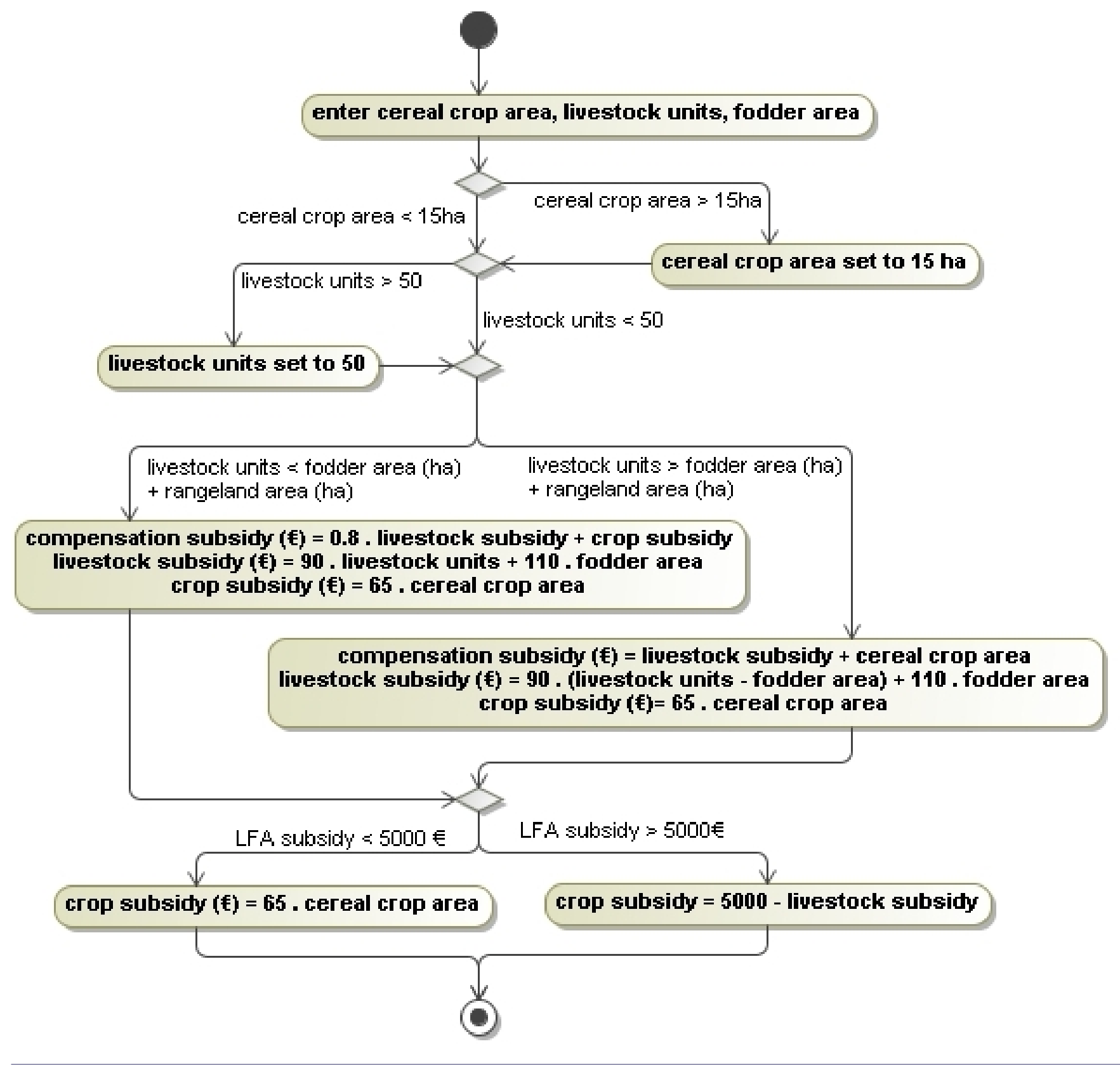


Table 4. Linear regression results for livestock subsidies (per farm and per head of livestock) as explanatory variables for stock-breeding intensification $(n=33)$.

\begin{tabular}{|c|c|c|c|c|c|}
\hline Variable type & Variable & Details & Coefficient & $\begin{array}{l}\text { Adjusted } \\
\mathrm{R}^{2}\end{array}$ & $P$-value \\
\hline Dependent variable & $\begin{array}{l}\text { Fodder variable costs per head } \\
\text { of livestock ( } € / \text { head) }\end{array}$ & Fodder-use intensity & & & \\
\hline Control variable & $\begin{array}{l}\text { Total small stock flock size in } \\
2005 \text { (heads) }\end{array}$ & Controls for flock-size effect & 0.09 & 0.37 & 0.0001 \\
\hline \multirow{6}{*}{$\begin{array}{l}\text { Independent } \\
\text { variables (tested } \\
\text { independently) }\end{array}$} & Holding LFA subsidy & & -0.007 & 0.41 & 0.09 \\
\hline & Holding ewe premium & & -0.004 & 0.40 & 0.12 \\
\hline & $\begin{array}{l}\text { Holding total livestock } \\
\text { subsidies }\end{array}$ & & -0.003 & 0.42 & 0.07 \\
\hline & $\begin{array}{l}\text { LFA subsidy per head of } \\
\text { livestock }\end{array}$ & & -1.5 & 0.37 & 0.31 \\
\hline & $\begin{array}{l}\text { Ewe premium per head of } \\
\text { livestock }\end{array}$ & $\begin{array}{l}\text { Light multicollinearity (variance } \\
\text { inflation factor }=10.64 \text { ) }\end{array}$ & -0.47 & 0.35 & 0.75 \\
\hline & $\begin{array}{l}\text { Total livestock subsidies per } \\
\text { head of livestock }\end{array}$ & $\begin{array}{l}\text { Light multicollinearity (variance } \\
\text { inflation factor }=10.43 \text { ) }\end{array}$ & -0.82 & 0.36 & 0.39 \\
\hline
\end{tabular}

Using average Cretan livestock farm attributes from FADN and Agris databases (Eurostat 2008a, $b$ ) as inputs for the model, we generated hypotheses on the influence of crops and livestock on CAP subsidies and on the resulting grazing pressure.

\section{Subsidies, agricultural practices, and land- degradation models}

We used multivariate linear-statistical models to test the links of HH/F subsidies and subsidies per head of livestock with intensification and flock growth on the one hand, and the intensification and flock growth with average vegetation-cover trend, dairy productivity, and profit on the other hand. The number of observations did not allow for integrating more than two explanatory variables per regression.

Each causative association (that is, intensification or flock growth) supposed by each hypothesis was tested by a linear regression including a control variable. A control variable is an independent variable that is not directly linked to the association to be tested but that is suspected to influence the dependent variable. Its inclusion in the regression allows testing the linear relationship among other independent variables and the dependent variable, independent of the influence of the control variable. In the regressions testing the intensification hypothesis, we used flock size as the independent variable, controlling for the effect that subsidies may have on flock growth, the "alternative hypothesis." The regressions testing the hypothesis of flock growth used the fodder costs per head of livestock as the control variable. Actually, subsidies may have caused intensification and flock growth simultaneously. The dependent and independent variables are provided in Tables 4-9. To minimize multicollinearity, we selected one variable among pairs of variables with a correlation coefficient $>0.8$ or inducing light multicollinearity. 
Figure 4. Less Favoured Area (LFA) subsidy as a function of sheep and goats per holding.

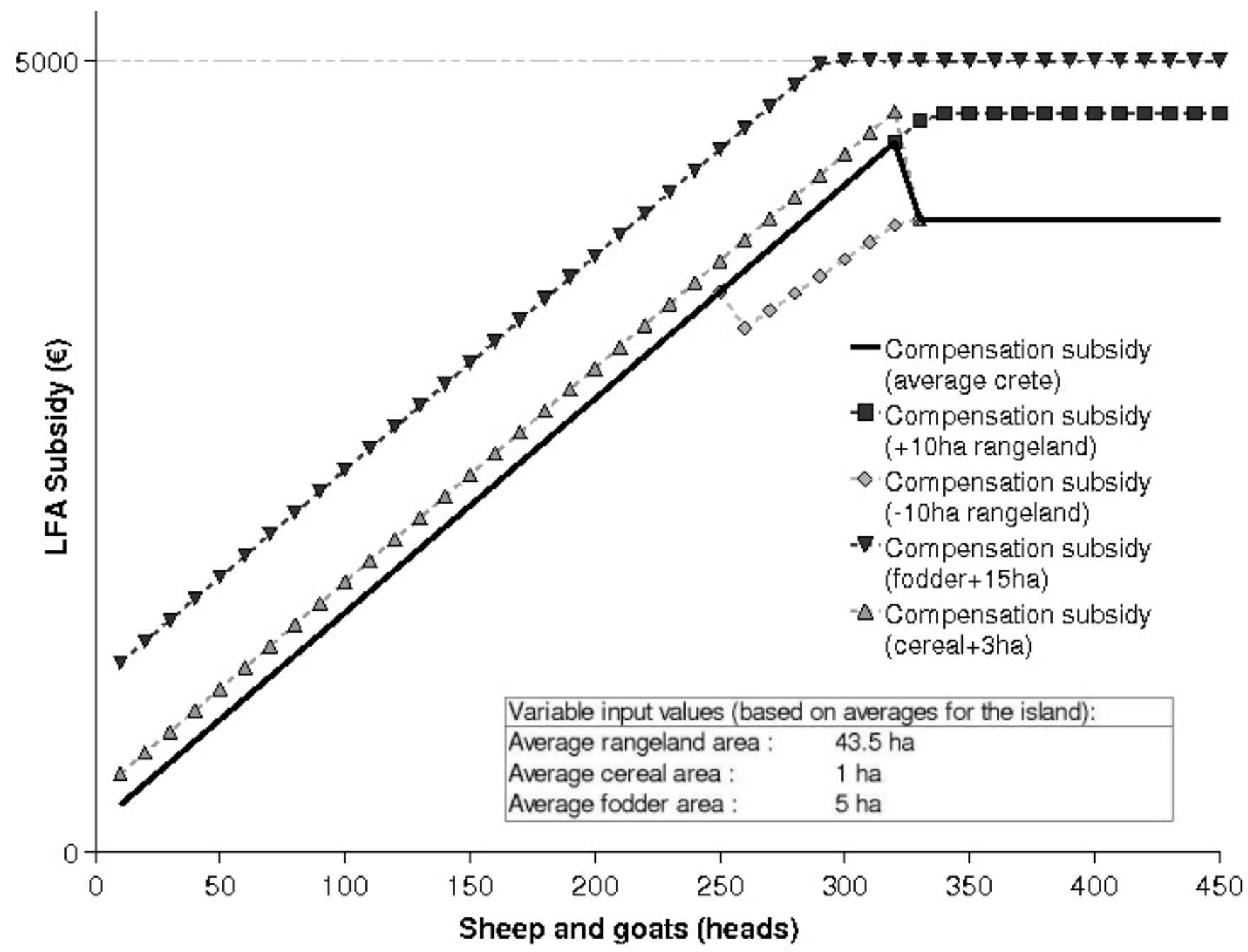

\section{Household/farm socioeconomic condition}

Eurostat (2003) defines Standard Gross Margin (SGM), or profitability, as the balance between the standard value of output, including subsidies, and the standard value of the proportional, or variable, costs that can easily be allocated to this output. Standard Gross Margin is expressed in monetary terms, either per ha of utilized agricultural area, or per head of livestock. The total SGM, or profit, of an agricultural unit is a linear function of the total amount of means of production and the balance between the output and the production costs of these different means. It is computed by multiplying the total amount of each type of production unit by its respective SGM. It also allows the classification of agricultural holdings by economic size and technical orientation (Eurostat 2003). We computed total SGM and SGM per head of livestock for each $\mathrm{HH} / \mathrm{F}$ to quantify the influence of subsidies on profit 
Table 5. Linear regression results for livestock subsidies level and intensity as explanatory variables for flock-size increase $(n=33)$.

\begin{tabular}{|c|c|c|c|c|}
\hline Variable type & Variable & Coefficient & $\begin{array}{l}\text { Adjusted } \\
\mathrm{R}^{2}\end{array}$ & $\begin{array}{l}p- \\
\text { value }\end{array}$ \\
\hline Dependent variable & Total number of sheep and goats & & & \\
\hline Control variable & $\begin{array}{l}\text { Fodder variable costs per head of livestock } \\
(€ / \text { head })\end{array}$ & 4.09 & 0.37 & $\begin{array}{l}<0.00- \\
01\end{array}$ \\
\hline \multirow{6}{*}{$\begin{array}{l}\text { Independent variables (tested } \\
\text { independently) }\end{array}$} & Holding LFA subsidy & 0.06 & 0.47 & 0.01 \\
\hline & Holding ewe premium & 0.03 & 0.45 & 0.02 \\
\hline & Holding total livestock subsidies & 0.03 & 0.46 & 0.005 \\
\hline & LFA subsidy per head of livestock & -9.6 & 0.36 & 0.33 \\
\hline & Ewe premium per head of livestock & -22.3 & 0.49 & 0.006 \\
\hline & $\begin{array}{l}\text { Total livestock subsidies per head of } \\
\text { livestock }\end{array}$ & -13.5 & 0.46 & 0.02 \\
\hline
\end{tabular}

and to assess the impact of farm practices on economic return.

\section{Macro- and microeconomic indicators}

We used a time series of deflated agricultural prices for Greece (Eurostat 2008a), taking 2005 as a reference year, to analyze the influence of market changes on $\mathrm{HH} / \mathrm{F}$ profit. We analyzed the evolution of FADN accountancy data, mainly profit and subsidies for sheep and goat enterprises in Crete between 1989-2005.

\section{RESULTS}

\section{Vegetation Cover and Trends}

The average values of vegetation-cover trends for the two village communities of the Psilorites were neutral, i.e., had values between -0.05 and 0.05 , whereas they were negative for the two communities in the Asterousia (Fig. 5a). Average vegetation cover in all four communities was $<30 \%$ (Fig. 5b). These averages were significantly different among the four villages (Table 10). The village communities in the Psilorites showed large zones of low vegetation cover scattered with patches having a high cover. Trends were largely neutral, with patches of increasing or decreasing vegetation cover. In the Asterousia, vegetation cover was generally $<40 \%$, with a few patches of higher cover in valley bottoms and steep slopes with poor accessibility. Patches with positive vegetationcover trends were found on forested southern slopes only.

At the household level, $19 \mathrm{HH} / \mathrm{F}$ grazing areas out of the 33 exhibited negative vegetation-cover trends on average, whereas the others had neutral cover trends. All $\mathrm{HH} / \mathrm{F}$ grazing areas had an average vegetation cover $<20 \%$. Note that $t=t$-value; $D F=$ degrees of freedom; and $p=p$-value. From the analysis of the impact of biophysical attributes of points sampled in $\mathrm{HH} / \mathrm{F}$ rangelands, average vegetation cover was found to be higher on flysch bedrock $(t=-2.58, D F=116, p=0.0116)$, but the vegetation-cover trend was declining significantly more often on flysch than on limestone bedrock $(t=7.47, D F=148, p=<0.001)$. Slope and altitude were not significantly correlated, at $<0.05$, to mean vegetation cover or to vegetation-cover trend. 
Figure 5. Vegetation-cover trend $(a)$ and mean vegetation-cover distribution $(b)$ in the four village communities.
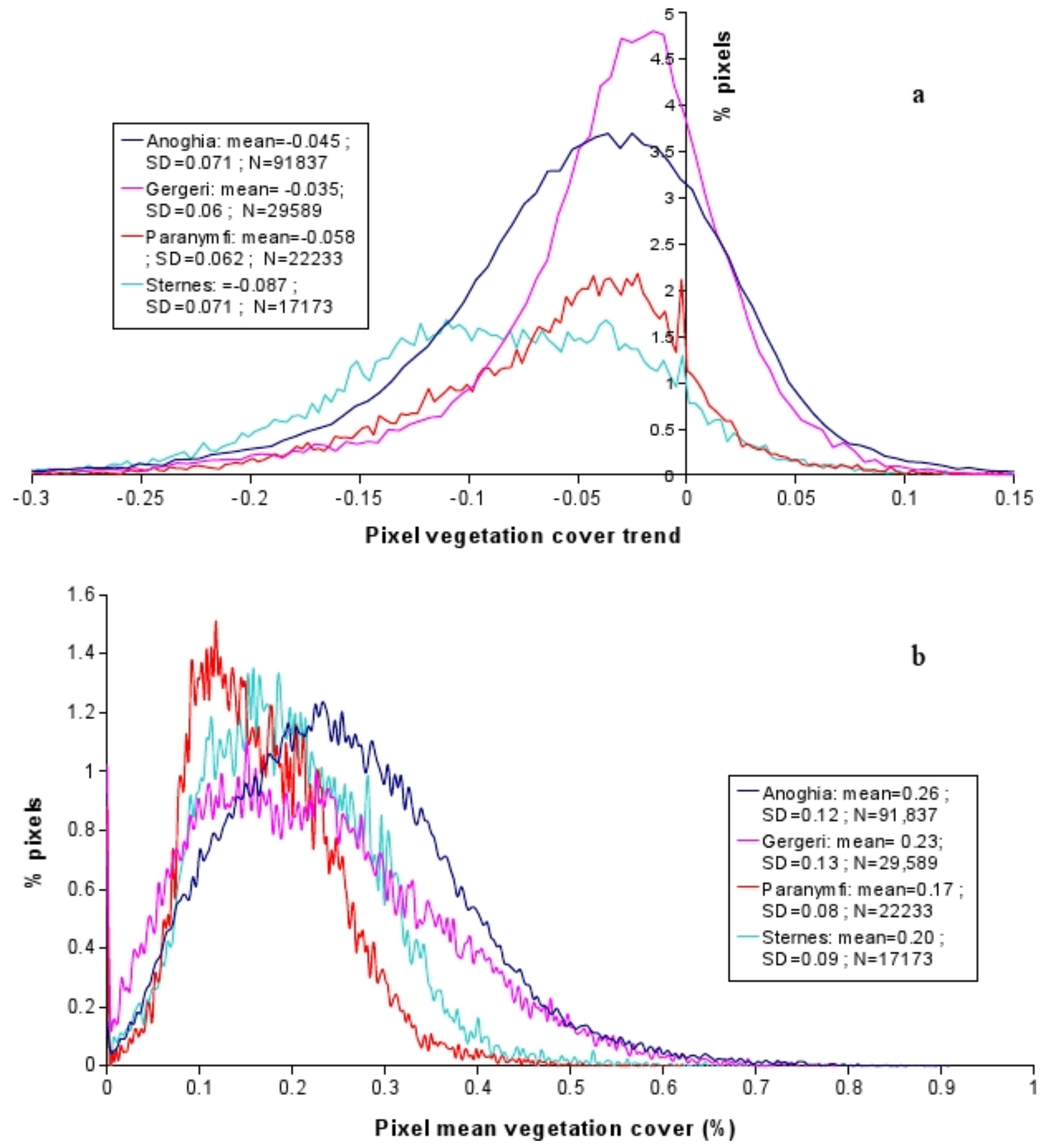
Table 6. Linear regression results for stock-breeding intensification as explanatory variable for average vegetation-cover trend of grazing areas $(n=33)$.

\begin{tabular}{|c|c|c|c|c|c|}
\hline Variable type & Variable & Details & Coefficient & $\begin{array}{l}\text { Adjusted } \\
\mathrm{R}^{2}\end{array}$ & $p$-value \\
\hline $\begin{array}{l}\text { Dependent } \\
\text { variable }\end{array}$ & $\begin{array}{l}\text { Average vegetation-cover trend of grazing } \\
\text { area }\end{array}$ & & & & \\
\hline Control variable & Total small stock flock size in 2005 (heads) & $\begin{array}{l}\text { Controls for flock-size } \\
\text { effect }\end{array}$ & 0.00002 & -0.003 & 0.51 \\
\hline $\begin{array}{l}\text { Independent } \\
\text { variable }\end{array}$ & $\begin{array}{l}\text { Fodder variable costs per head of livestock } \\
(€ / \text { head })\end{array}$ & & -0.0005 & 0.13 & 0.02 \\
\hline
\end{tabular}

\section{Subsidies-Allocation Model}

The ewe premium is allocated per head of productive livestock, at a rate of $€ 16.8 /$ head. An additional premium of $€ 7.95 /$ head is granted in mountainous areas, where sheep and goat breeding is traditional or helps sustain the rural economy. No stocking-density criterion restricts the payment of this premium (Canali 2005, District of Crete 2006). Although the ewe premium aims to ensure a fair income to farmers (Council Regulation 2529/2001), the objective of the LFA compensation subsidy is to support sustainable rural development (Council Regulation 1257/99). The LFA subsidy increases linearly with LU (Fig. 4), and then levels off. Increasing cereal-crop area increases the intercept and, therefore, the maximum of $€ 5000$ is reached for a smaller number of livestock. Cereal subsidy is restricted to $65 € /$ ha and has a limited impact on flock size. Fodder-crop areas receive $€ 110 /$ ha, thus increasing the intercept, and allowing for larger flocks as they are included in the total area limiting the subsidized LU.

\section{CAP Subsidies and Husbandry Practices}

Common Agricultural Policy livestock subsidies, per farm and per head of livestock, were not significantly related to fodder-use intensity when controlling for flock size (Table 4). The ewe premium, the LFA subsidy, and their sum per holding were significantly and positively correlated with flock size (Table 5). Subsidies per head for the ewe premium were negatively correlated with flock size. When looking at the control variables, total flock size and fodder costs per head were positively correlated.

\section{Agricultural Practices, Productivity, and Land Degradation}

Vegetation-cover trend was negatively linked with concentrated fodder costs per head of livestock (Table 6). No significant linear relation was found between average vegetation-cover trend and flock size or grazing pressure (Table 7). Livestock productivity was negatively associated with flock size (Table 8), but no significant relation was found with intensification. Farm profit for livestock was significantly and negatively correlated with flock size and fodder-use intensity (Table 9).

\section{Economic Indicators}

Deflated prices of hay and other fodders in Greece increased substantially over recent years (Fig. 6). The prices of sheep, goats, and milk remained stable (Fig. 7). Fodder costs represent an important part of the costs of sheep and goat specialists (Fig. 8). Total livestock subsidies per farm increased between 1989-2005 (Fig. 9). 
Figure 6. Deflated agricultural price indices for the main inputs of the livestock sector in Greece (reference year $=2005$; Eurostat).

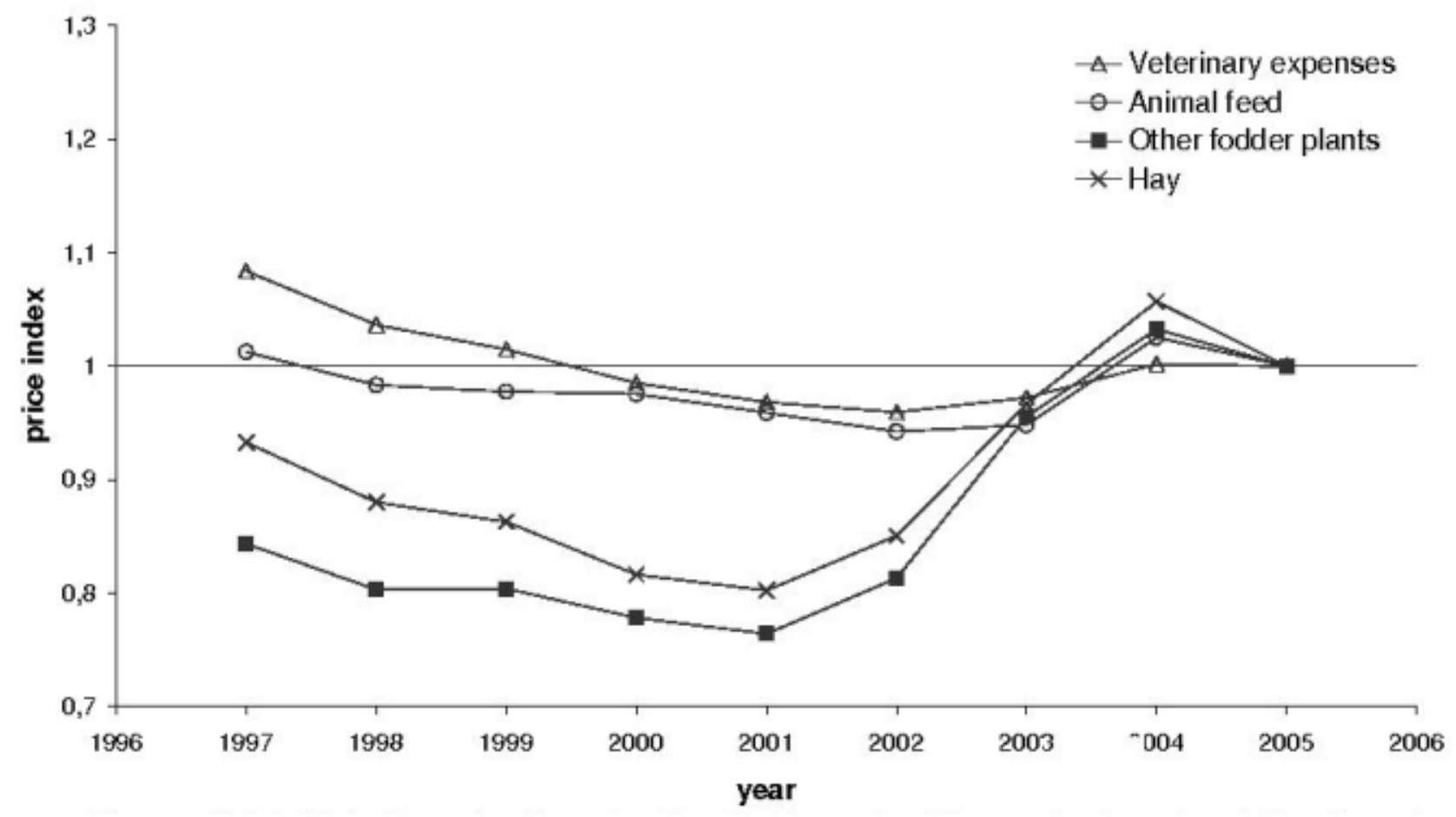

\section{DISCUSSION}

In the rangelands grazed by the flocks of the $\mathrm{HH} / \mathrm{F}$ interviewed, there is a trend toward decreasing vegetation cover in the Asterousia and no general trend in the Psilorites. Low vegetation cover provides a poor protection against soil erosion (Thornes 1990, Ludwig et al. 2000). Unexpectedly, there was no statistical association in space between increasing flock sizes and vegetation degradation. Rather, areas most prone to vegetation-cover decrease were associated with flysch substratum.

When considering the way subsidies are allocated to $\mathrm{HH} / \mathrm{F}$, the ewe premium is given to farmers according to the rights that they own and that they may either acquire or inherit (Council Regulation 2529/2001). This represents an incentive for farmers to increase the size of their flocks. The LFA subsidy limits flock growth, as it imposes a significant penalty when a certain grazing pressure is exceeded. However, its calculation has some drawbacks. Farmers maximize this subsidy by increasing stocking densities. This can lead to excessive grazing pressure. Further, such high stocking densities can only be sustained based on external fodder inputs. The LFA subsidy allows holdings with flocks greater than the maximum of $50 \mathrm{LU}$ to avoid the penalty, provided that their forage area exceeds 50 ha and that the marginal profit of extra, nonsubsidized animals remains positive. To escape the penalty once the sum of rangeland and fodder areas exceed 50 ha, farmers could omit declaring the extra animals that would not be subsidized. The marginal utility of the ewe premium then becomes lower than the penalty in absolute terms. By not declaring extra animals, they maximize the LFA subsidy. This is suggested by the negative association between livestock subsidies per head and flock size. According to the LFA 
Table 7. Linear regression results for stock number and grazing pressure as explanatory variables for average vegetation-cover trend of grazing areas $(n=33)$.

\begin{tabular}{|c|c|c|c|c|c|}
\hline Variable type & Variable & Details & Coefficient & $\begin{array}{l}\text { Adjusted } \\
\mathrm{R}^{2}\end{array}$ & $p$-value \\
\hline Dependent variable & $\begin{array}{l}\text { Average vegetation-cover trend of } \\
\text { grazing area }\end{array}$ & & & & \\
\hline Control variable & $\begin{array}{l}\text { Fodder variable costs per head of } \\
\text { livestock ( } € / \text { head) }\end{array}$ & $\begin{array}{l}\text { Controls for fodder use } \\
\text { intensity }\end{array}$ & -0.0004 & 0.14 & 0.017 \\
\hline \multirow{4}{*}{$\begin{array}{l}\text { Independent } \\
\text { variables (tested } \\
\text { independently) }\end{array}$} & Total number of sheep and goats & & 0.00002 & 0.13 & 0.511 \\
\hline & Total number of sheep & & 0.00002 & 0.12 & 0.61 \\
\hline & Total number of goats & & 0.00004 & 0.13 & 0.53 \\
\hline & Grazing pressure on rangelands & & 0.001 & 0.12 & 0.59 \\
\hline
\end{tabular}

model, the penalty is thus likely to be applied to smaller enterprises that do not have access to large grazing areas or encourages farmers not to declare extra animals.

The LFA subsidy does not stimulate stockbreeders to produce cereals for concentrated fodder. Fodder crops are supported at a higher rate (€110/ha compared with $€ 65 /$ ha for cereals), have lower production costs, and are included in the calculation of the stock limitation. The limited access to suitable land could also restrict cereal production by stockbreeders with limited investment capacity, whereas rangelands can be easily converted to meadows. In the two municipalities of the Asterousia, rangelands have been converted to technical meadows sown with barley, or "chasilia" in Greek. This allows the production of fresh fodder at a low cost, and a simultaneous increase in subsidized fodder areas while maintaining the same total forage area for the calculation of the grazing pressure threshold for LFA subsidies. Chasilia increases soil-erosion risk by reducing vegetation cover and root depth, especially when downslope plowing is applied (Fig. 10).

Neither of our two alternative hypotheses about the role of subsidies on land-use practices were supported by the data. However, although the hypothesis on intensification was not verified, the positive influence of subsidies on flock growth was confirmed statistically in the range of values observed in our sample. The linear relationship between average vegetation-cover trend and intensification was opposite to what was expected. Although subsidies did indeed stimulate the growth of flocks up to a point, the impact of higher grazing pressure on vegetation cover was not statistically significant. Given the low and, in some places, declining vegetation cover in rangelands and the use of fodder as main source of feed for grazers, we conclude that a decoupling between rangeland vegetal primary production and grazers' secondary production occurred. Given the negative relationship between intensification and vegetation-cover trend, the use of concentrated fodder could be a consequence of a decreasing vegetal biomass.

Based on our statistical results, we propose an alternative explanation for land degradation in central Crete over the last two decades. This explanation is that CAP livestock subsidies stimulated the growth of the herds to a certain level. As available grazing areas remained constant, grazing pressure increased until the average carrying capacity of rangelands was exceeded. All 
Figure 7. Deflated agricultural price indices for the main outputs of the livestock sector in Greece (reference year $=2005$; Eurostat).

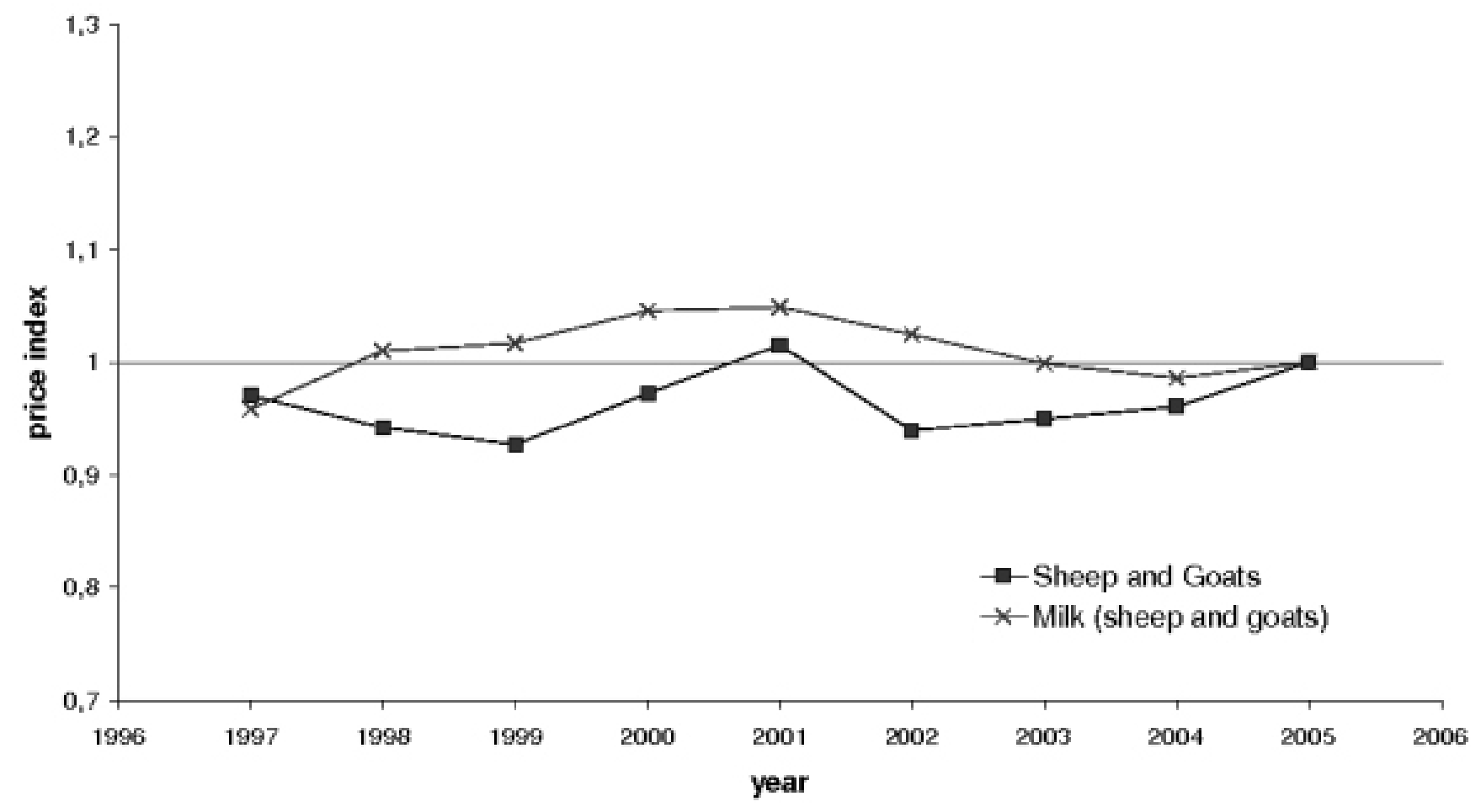

rangelands in central Crete were intensively grazed and remained sparsely covered with vegetation species adapted to high grazing pressures. Whereas goats can feed on some of these species, sheep require substantial additional fodder under such conditions. In some places, primary productivity further decreased, as reflected by vegetation-cover trends. Fodder inputs purchased off farm were thus required to feed the stocks. Rangelands lost their primary role of feed supply for grazers but were still used by shepherds as paddocks, providing some fresh feed seasonally. However, the increased use of concentrated fodder purchased off farm might have also been driven by external factors, such as improved access to markets, or advice from extension services. External feed supplements might have led to the abandonment of transhumance and to overgrazing.
Flock growth has also had socioeconomic consequences at the farm level. Bigger flocks use comparatively more concentrated fodder bought off-farm, in agreement with Ricardo's law of decreasing yields (Pasinetti 1960), produce less milk per animal and, in the absence of a subsidy, generate lower profits when they exceed a certain size. Milk-extraction efficiency decreases with flock size, as labor inputs do not grow proportionally with herd size. Animal health may also decrease with increasing livestock density. Bigger farms do not seem to benefit from economies of scale. Furthermore, farmers receive fewer subsidies per head of livestock once they enlarge their flocks beyond the administrative limits of the LFA subsidy. Many of the farmers questioned had recorded a loss for the year covered by the survey. These nonremunerative situations are not only the result of a decrease in profitability linked to the 
Table 8. Linear regression results for stock-breeding intensification and flock size as explanatory variables for change in stock productivity $(n=31)$.

\begin{tabular}{|c|c|c|c|c|c|}
\hline Variable type & Variable & Details & Coefficient & $\begin{array}{l}\text { Adjusted } \\
\mathrm{R}^{2}\end{array}$ & $p$-value \\
\hline Dependent variable & Milk productivity per head of livestock & $\begin{array}{l}\text { Two holdings were } \\
\text { excluded as they did not } \\
\text { produce milk }\end{array}$ & & & \\
\hline \multirow[t]{2}{*}{$\begin{array}{l}\text { Independent } \\
\text { variables }\end{array}$} & $\begin{array}{l}\text { Total small stock flock size in } 2005 \\
\text { (heads) }\end{array}$ & & -0.05 & 0.14 & 0.01 \\
\hline & $\begin{array}{l}\text { Fodder variable costs per head of } \\
\text { livestock }(€ / \text { head })\end{array}$ & & 0.22 & & 0.09 \\
\hline
\end{tabular}

number of animals, but are also reflective of recent trends in agricultural commodity prices. Between 1995-2005, the livestock sector's output prices remained stable, whereas the price of main inputs increased significantly after 2001. Past favorable market conditions supported the increase in flock sizes with positive profits. The recent rise in input prices pushed farms with larger flocks into unprofitable situations. Although subsidies are viewed as a buffer that reduces the economic vulnerability of $\mathrm{HH} / \mathrm{Fs}$ to market fluctuations, in reality their maximization made stockbreeders less adaptive and more sensitive to market changes.

People living in remote areas of Greece have few opportunities to improve their socioeconomic welfare. The limited local employment options and the weak social-safety net greatly limit off-farm income, and raising livestock is often seen as the main employment source (Iosifides and Politidis 2005). Coping strategies, such as diversifying production with olive oil or increasing the number of family members belonging to the same household (Matsaganis 2001), are limited. People might thus be tempted to find alternative income sources in cities, and this is reflected in the rural exodus that took place during the second half of the 20th century (Papanastasis 1993, Lyrintzis 1996). However, some local initiatives have succeeded in sustaining the livestock sector. An example is a cooperative cheese factory that was started in Anoghia.

The policies applied by the Greek Ministry of Agriculture, an organization that is in charge of both agricultural expansion and the national action plan against desertification (Greek National Committee for Combatting Desertification 2001, 2002), may be a cause of socioeconomic and biophysical degradation in the livestock sector. The objectives of providing income support and preventing of land degradation are sometimes contradictory (Juntti and Wilson 2005). In the case of subsidies, the administration implements rules defined at the European level. The marginal importance of sheep and goat husbandry in the European dimension means that their specificities are not fully taken into account in the definition of these policies (de Rancourt et al. 2005).

What would have happened without subsidies? Sheep and goat milk production would probably not have developed at the same scale. The market would not have expanded much further than the national level, and milk would often have been processed on the farm and distributed locally or consumed at home. Roads would likely not have been built for stockbreeders as was done in the 1990s with EU funds, and market access would thus have remained limited. Less genetic improvement of flocks would have been possible, thus keeping productivity levels low. The number of farms would not have decreased as much as it did, keeping smaller flocks and a higher dependency on rangeland production for their feeding. When grazed at a low intensity, rangelands in central Crete can play an important role in grazing systems, especially if a rest period is included in the grazing practices (Papanastasis and Misbah 1998). A combination of low- and high-altitude 
Figure 8. Average livestock specific costs for sheep and goat specialists in Crete between 1989-2005 (FADN).

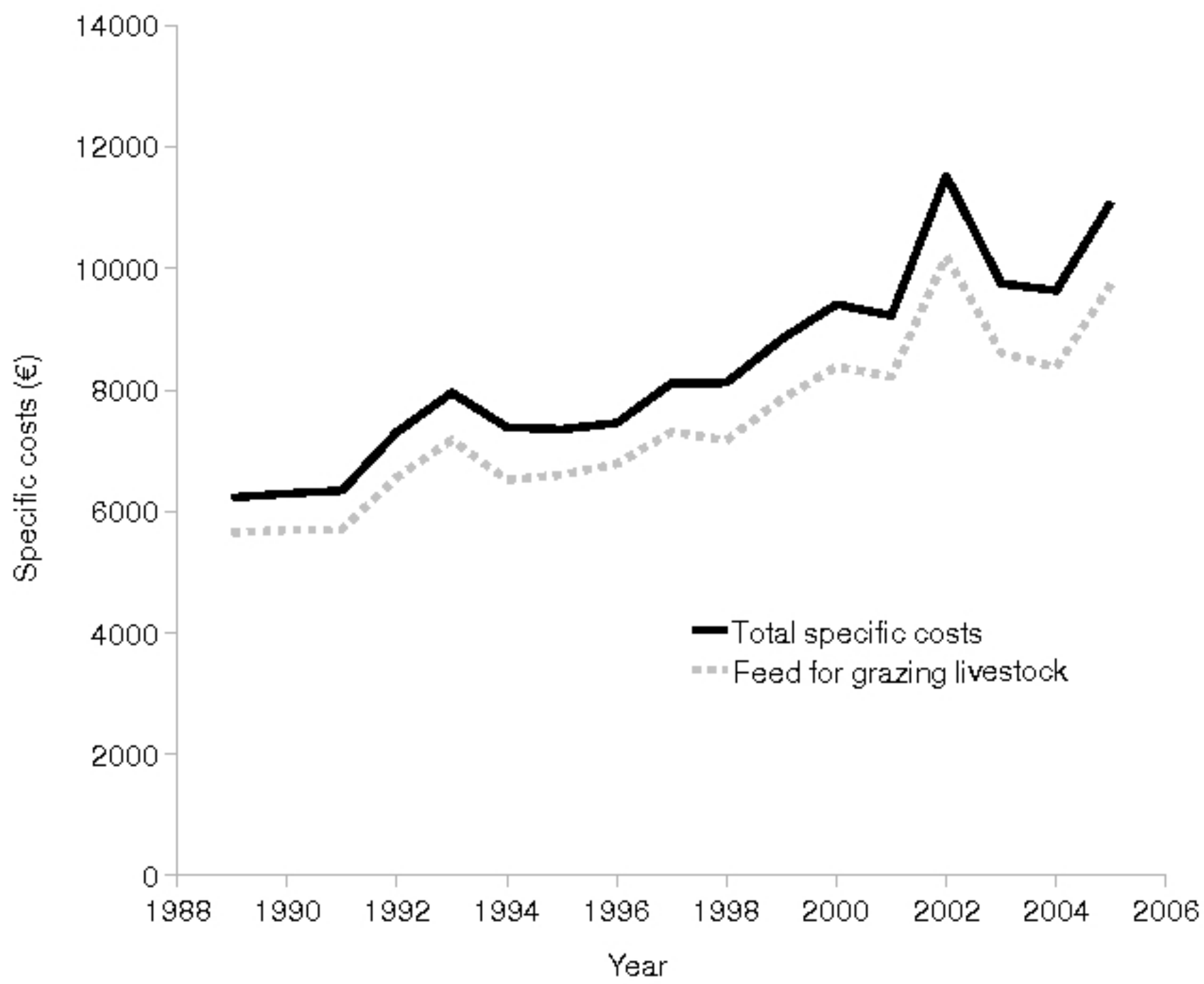

rangelands, corresponding to the traditional transhumant system, could provide fodder for a 10month period annually (Kyriakakis and Papanastasis 1997). If such practices had been implemented, concentrated fodder would still have been used, but the limited purchasing ability and access to the market of stock-breeding households would have restricted this practice to summers or dry periods. The lower dependency on dietary supplements bought off-farm would have kept stockbreeders less exposed to input-price fluctuations. Producers would have been better informed about agricultural commodity prices on the local market and would have had a stronger influence on prices, although local market functioning may exacerbate economic vulnerability of small stock owners in post-drought periods (Turner and Williams 2002). 
Table 9. Linear regression results for stock-breeding intensification and flock size as explanatory variables for change in livestock profit $(n=30)$.

\begin{tabular}{|c|c|c|c|c|c|}
\hline Variable type & Variable & Details & Coefficient & $\begin{array}{l}\text { Adjusted } \\
\mathrm{R}^{2}\end{array}$ & $p$-value \\
\hline $\begin{array}{l}\text { Dependent } \\
\text { variable }\end{array}$ & Holding total livestock profit $(€)$ & $\begin{array}{l}\text { Two holdings excluded as they did } \\
\text { not produce milk; one household } \\
\text { excluded because profit could not } \\
\text { be computed }\end{array}$ & & & \\
\hline \multirow[t]{3}{*}{$\begin{array}{l}\text { Independent } \\
\text { variables }\end{array}$} & $\begin{array}{l}\text { Total small stock flock size in } \\
2005 \text { (heads) }\end{array}$ & & -64.8 & 0.78 & $<0.001$ \\
\hline & & & & & 0 \\
\hline & $\begin{array}{l}\text { Fodder variable costs per head } \\
\text { of livestock ( } € / \text { head })\end{array}$ & & -249 & & \\
\hline
\end{tabular}

The new subsidy regime applied to farmers and stockbreeders by EU member states between 20042006, called the Single Payment Scheme (SPS), has modified the incentives for land-use practices (Council Regulation 1782/2003). It is expected to lead to different environmental and social impacts. One of the main purposes of the SPS is to help farmers and stockbreeders to adapt to market prices, preceding a greater liberalization of the European agricultural market. Nevertheless, farmers remain poorly informed by national and European authorities about the implications of structural changes in the CAP and on the evolution of prices in a globalized market.

This study would have gained from several methodological improvements. First, representing the dynamics of both environmental and socioeconomic conditions would have required a longitudinal study with successive field surveys. Instead of a cross-sectional analysis, a panel analysis based on a larger sample of households would have been more appropriate, but this was not possible due to time and financial constraints. Gaining access to stock breeders in village communities was not an easy task. We interviewed up to one-third of the farm managers in two of the village communities. Consequently, we could not control for the potential effect of social networks in the sampling of interviewees.

\section{CONCLUSION}

We have analyzed how livestock subsidies under the CAP regime preceding the 2003 reform affected the practices of sheep and goat farms and land degradation in central Crete. The analysis of a highresolution time series of satellite data revealed a low and, in some places, decreasing trend for vegetation cover in the rangelands of the study area. By modeling the attribution of subsidies to holdings, we showed that the allocation system has induced individual flock-size increases up to a point, and has caused land-use changes leading to the risk of increasing soil erosion. Linking remote-sensing and farm-survey data, we tested two alternative hypotheses on the influence of CAP subsidies on farmers' practices and the link between these practices and vegetation-cover change. Multivariate linear regressions suggested that subsidies stimulated flock growth accompanied by intensification and a decrease in productivity and profitability. There was no statistical association in space between increasing flock sizes and vegetation degradation. From these findings, we conclude that CAP subsidies induced the decoupling of sheep and goat holdings from rangeland production. Farmers who increased their flocks to maximize CAP subsidies became more sensitive and less adaptive to adverse price changes in agricultural commodities, pushing some of them temporarily into unprofitable situations. 
Table 10. Statistical differences in pixel mean vegetation cover and vegetation-cover trend between the rangeland areas of the four village communities. Values in cells located in the upper right of the diagonal refer to $t$-tests run on vegetation-cover trend; values in the lower left refer to $t$-tests run on mean vegetationcover values ( $t=t$-value; $D F=$ degrees of freedom, $p=p$-value).

\begin{tabular}{lllll}
\hline \hline & Anoghia & Gergeri & Paranymfi & Sternes \\
\hline Anoghia & & $t=34.6046$ & $t=101.2592$ & $t=59.2448$ \\
& & $D F=121424$ & $D F=114068$ & $D F=109008$ \\
& $p<0.0001$ & $p<0.0001$ & $p<0.0001$ \\
Gergeri & $t=23.7186$ & & $t=59.908$ & $t=26.323$ \\
& $D F=121424$ & & $D F=51820$ & $D F=46760$ \\
& $p<0.0001$ & & $p<0.0001$ & $p<0.0001$ \\
Paranymfi & $t=25.0258$ & $t=43.3108$ & & $t=34.368$ \\
& $D F=114068$ & $D F=51820$ & & $D F=39404$ \\
& $p<0.0001$ & $p<0.0001$ & & $p<0.0001$ \\
Sternes & $t=70.8368$ & $t=83.3486$ & $t=43.2111$ & \\
& $D F=109008$ & $D F=46760$ & $D F=39404$ & \\
& $p<0.0001$ & $p<0.0001$ & $p<0.0001$ & \\
\hline
\end{tabular}


Figure 9. Average amount of subsidies received by sheep and goat specialists in Crete between 19892005 (FADN).

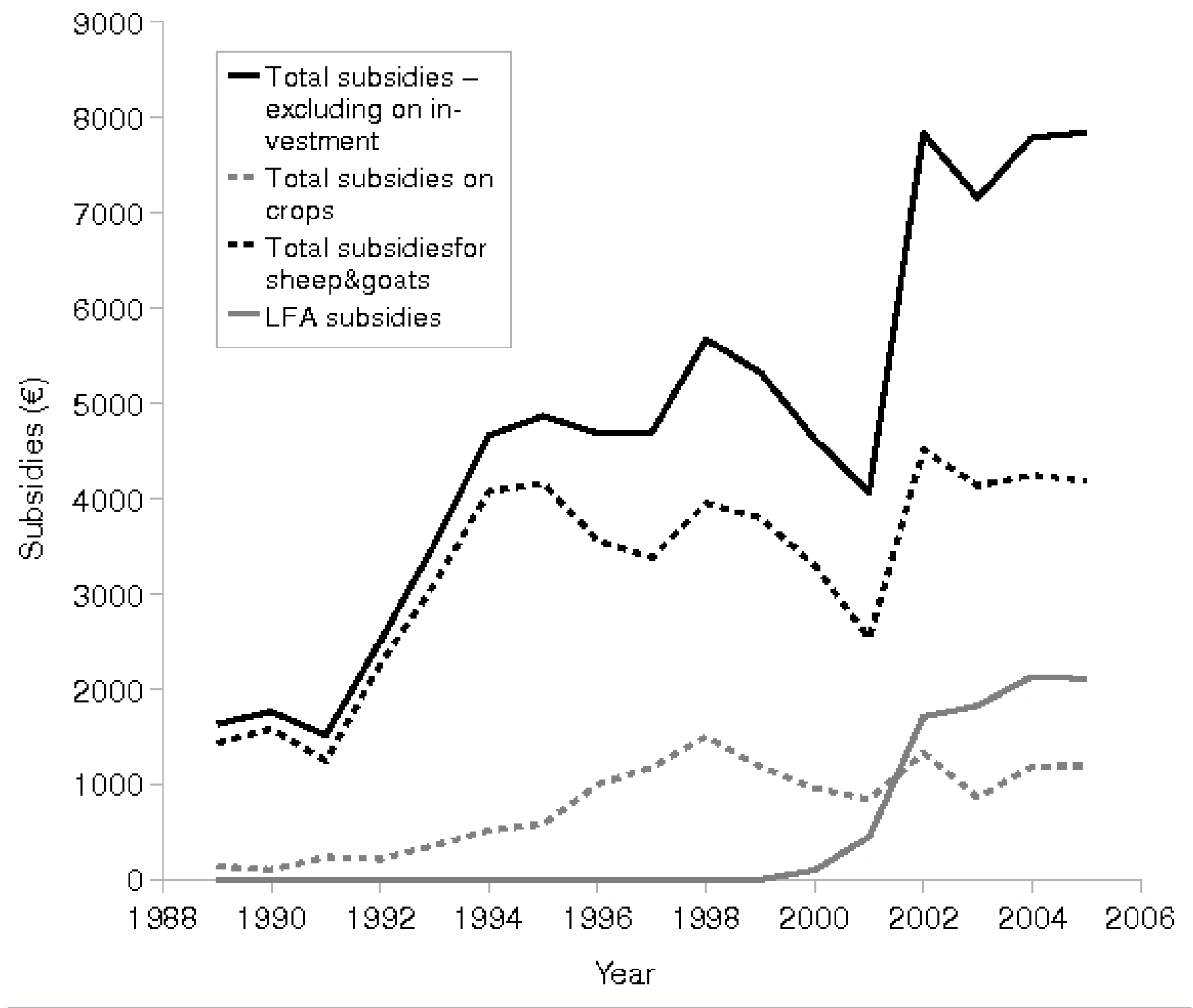


Figure 10. Land-use changes suspected to be provoked by LFA subsidies (Asterousia). Dark green areas are rangeland covered with phrygana. The light green areas, above and under the shed in the picture, are rangeland recently converted to barley meadows. Plough lines along the slope and starting gullies linked to this land-use change are visible in the picture.

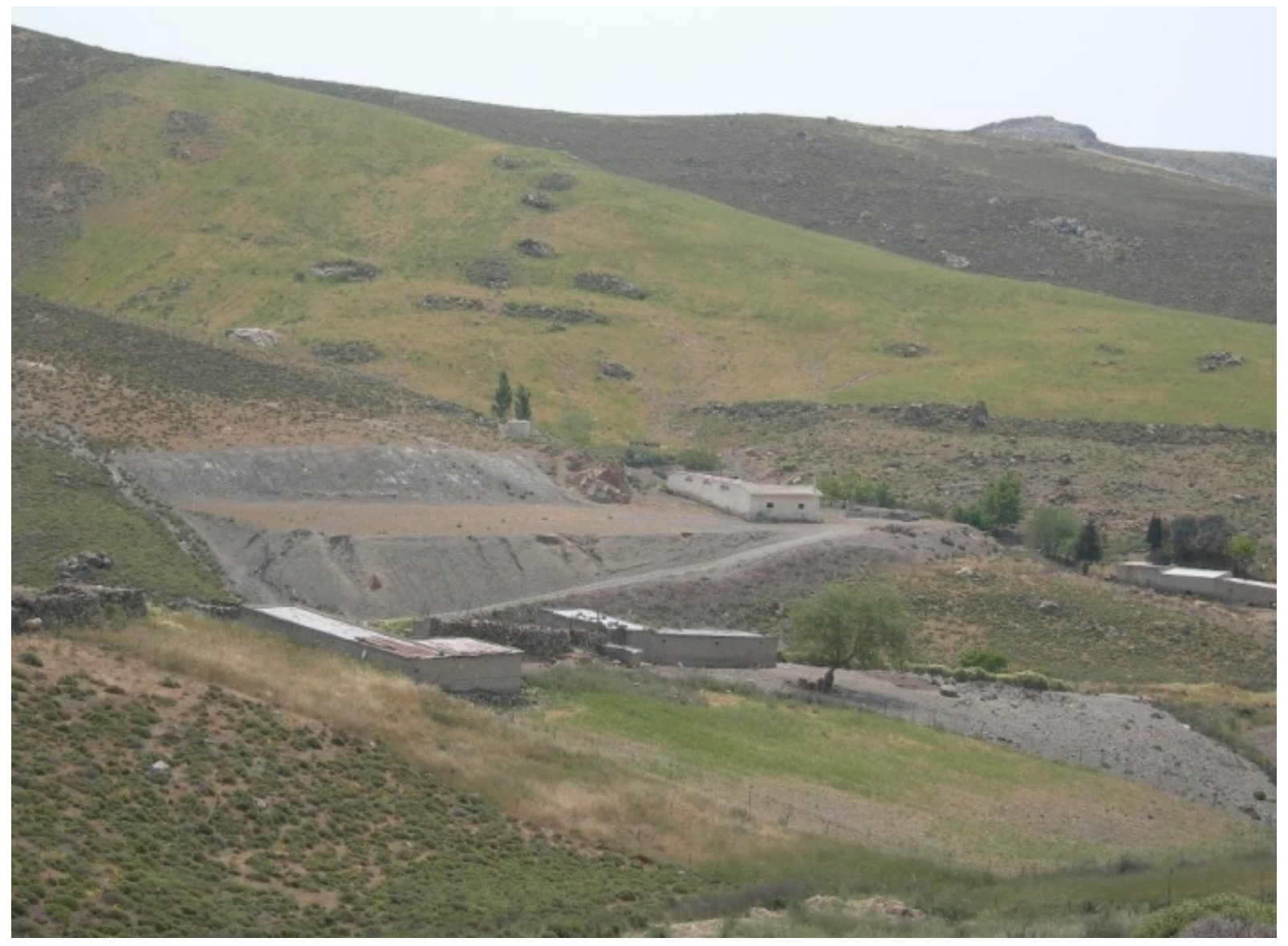


Responses to this article can be read online at: http://www.ecologyandsociety.org/voll4/iss2/art41/ responses/

\section{Acknowledgments:}

This research has been realized in the framework of the DeSurvey IP, funded by the Sixth Framework Program of the European Commission. The content of the publication does not represent the views of the Commission or its services. The author would like to thank Theresa Schiller for her valuable help in realizing the field interviews, and Rosalind Fredericks for the unexpected impulse that she gave to the discussion of this paper.

\section{LITERATURE CITED}

Berzborn, S. 2007. The household economy of patoralists and wage-labourers in the Richtersveld, South Africa. Journal of Arid Environments 70:672-685.

Boardmann, J., J. Poesen, and R. Evans. 2003. Socioeconomic factors in soil erosion and conservation. Environmental Science and Policy 6:1-6.

Boix, C., A. Calvo, A. C. Imeson, J. M. Schoorl, S. Soto, and I. R. Tiemessen. 1995. Properties and erosional response of soils in a degraded ecosystem in Crete (Greece). Environmental Monitoring and Assessment 37:79-92.

Canali, G. 2005. Common Agricultural Policy reform and its effects on sheep and goat market and rare breeds conservation. Small Ruminant Research 62:207-213.

Cerda,A. 1998. Relationships between climate and soil hydrological and erosional characteristics along climatic gradients in Mediterranean limestone areas. Geomorphology 25(1-2):123-134.

de Rancourt, M., N. Fois, M. P. Lavín, E. Tchakérian, and F. Vallerand. 2005. Mediterranean sheep and goats production: an uncertain future. Small Ruminant Research 62:167-179.
District of Crete. 2006. Indices for the computation of agricultural income, year 2005. Administration for Agricultural Extension, Heraklio, Crete, Greece.

Eurostat. 2003. Structure and typology of agricultural holdings. European Commission, Brussels, Belgium. 322:1-3.

Eurostat. 2008a. Agriculture, forestry and fisheries online database. European Commission, Brussels, Belgium. [online] URL: http://epp.eurostat.ec.europa. eu/portal/page/portal/agriculture/data/database.

Eurostat. 2008b. Farm Accountancy Data Network (FADN) online database. European Commission, Brussels, Belgium. [online] URL: http://ec.europa. eu/agriculture/rica/database/database.cfm.

Gillson, L., and M. T. Hoffman. 2007. Rangeland ecology in a changing world. Science 315:53-54.

Greek National Committee for Combating Desertification (GNCCD). 2001. First national report of Greece on the implementation of the United Nations Convention to Combat Desertification. Ministry of Agriculture, Athens, Greece. [online] URL: http://www.unccd.int/cop/reports/northmed/ national/2000/greece-eng.pdf.

Greek National Committee for Combating Desertification (GNCCD). 2002. Second national report of Greece on the implementation of the United Nations Convention to Combat Desertification. Ministry of Agriculture, Athens, Greece. [online] URL: http://www.unccd.int/cop/reports/northmed/ national/2002/greece-eng.pdf.

Hatzianastassiou, N., B. Katsoulis, J. Pnevmatikos, and V. Antakis. 2008. Spatial and temporal variation of precipitation in Greece and surrounding regions based on global precipitation climatology project data. Journal of Climate 21(6):1349-1370.

Hill, J., P. Hostert, G. Tsiourlis, P. Kasapidis, Th. Udelhoven and C. Diemer. 1998. Monitoring 20 years of increased grazing impact on the Greek island of Crete with earth observation satellites. Journal of Arid Environments 39(2):165-178.

Hostert, P., A. Röder, J. Hill, T. Udelhoven, and G. M. Tsiourlis. 2003. Retrospective studies of grazing-induced land degradation: a case study in 
central Crete, Greece. International Journal of Remote Sensing 24(20):4019-4034.

Iosifides, T., and T. Politidis. 2005. Socioeconomic dynamics, local development and desertification in Western Lesvos, Greece. Local Environment 10(5):487-499.

Juntti, M., and G. Wilson. 2005. Conceptualizing desertification in southern Europe: stakeholder interpretations and multiple policy agendas. European Environment 15:228-249.

Kyriakakis, S. D., and V. P. Papanastasis. 1997. Seasonal changes in rangeland production in relation to altitude in western Crete. Pages 155-158 in Proceedings of the Ninth Meeting of the Mediterranean Sub-Network of the FAO-CIHEAM Inter-Regional Cooperative Research and Development Network on Pastures and Fodder Crops. Food and Agriculture Organization (FAO), Centre International des Hautes Etudes Agronomiques Méditerranéennes (CIHEAM), Universidad de Extremadura, Junta de Extremadura, and the Institute of Agricultural Research (INIA). 26-29 November 1997, Badajoz, Spain.

Lorent, H., C. Evangelou, M. Stellmes, J. Hill, V. P. Papanastasis, G. M. Tsiourlis, A. Roeder, and E. F. Lambin. 2008. Land degradation and economic conditions of agricultural households in a marginal region of northern Greece. Global and Planetary Change 64(3-4):198-209.

Ludwig, J.A., G. N. Bastin, R. W. Eager, R. Karfs, P. Ketner, and G. Pearce. 2000. Monitoring Australian rangeland sites using landscape function indicators and ground- and remote-based techniques. Environmental Monitoring and Assessment 64(1):67-178.

Lyrintzis, G. 1996. Human impact trend in Crete: the case of Psilorites mountains in Crete. Environmental Conservation 23(2):140-148.

Matsaganis, M. 2001. Prerequisites to minimum income reform in Greece. Improving Minimum Income Systems in the EU, Seminar. 9-10 February 2001, Leuven, Belgium. [online] URL: https://lirias. kuleuven.be/handle/123456789/190279.

Menjli, M., and V. P. Papanastasis. 1995. Impact of pastoralism on desertification of Psilorites mountain in Crete, Greece. Pages 361-362 in Rangelands in a Sustainable Biosphere, Proceedings of the Fifth International Rangeland Congress. Society for Range Management, Denver, Colorado, USA.

Naoum, S., and I. K. Tsanis. 2003. Temporal and spatial variation of annual rainfall on the island of Crete, Greece. Hydrological Processes 17:18991922.

National Statistical Service of Greece (NSSG). 2009. Agricultural price indices. Ministry of Economy and Finance of the Hellenic Republic. Athens, Greece. http://www.statistics.gr/portal/page/ portal/ESYE/PAGE-themes?p param=A0499.

Papanastasis, V. P. 1998. Grazing intensity as an index of degradation in semi-natural ecosystems: the case of Psilorites mountains in Crete. Pages 146168 in Proceedings of the International Seminar on Indicators for Assessing Desertification in the Mediterranean. 18-20 September 1998, Porto Torres, Italy.

Papanastasis, V. P., and D. Misbah. 1998. Effects of livestock grazing on productivity of kermes oak silvopastoral system in the Psilorites mountains of Crete (Greece). Annales de la Recherche Forestiere au Maroc 51-65.

Papanastasis, V.P. 1993. Legal status of land tenure and its implication for open landscapes of western Crete. Landscape and Urban Planning 24:273-277.

Pasinetti, L. L. 1960. A mathematical formulation of the Ricardian system. The Review of Economic Studies 27(2):78-98.

Rindfuss, R. R., S. J. Walsh, V. Mishra, J. Fox, and G. P. Dolcemascolo. 2003. Linking household and remotely sensed data: methodological and practical problems. Pages 1-29 in J. Fox, R. R. Rindfuss, S.J. Walsh, and V. Mishra, editors. People and the environment: approaches for linking household and community surveys to remote sensing and GIS. Springer, Berlin, Germany.

Röder, A., Th. Udelhoven, J. Hill , G. del Barrio, and G. Tsiourlis. 2008. Trend analysis of LandsatTM and -ETM+ imagery to monitor grazing impact in a rangeland ecosystem in northern Greece. Remote Sensing of Environment 112(6):2863-2875. 
Sonnenschein, R. 2008. Maps of land-use/cover change and land degradation status for the Crete test site. DeSurvey Integrated Project, Deliverable D 1.5.2.8. European Commission, Brussels, Belgium.

Stafford Smith, M., G. M. McKeon, I. W. Watson, B. K. Henry, G. S. Stone, W. B. Hall, and S. M. Howden. 2007. Learning from episodes of degradation and recovery in variable Australian rangelands. Proceedings of the National Academy of Science 104(52):20690-20695.

Thornes, J. B. 1990. The interaction of erosional and vegetational dynamics in land degradation: spatial outcomes. Pages 41-54 in J. B. Thornes, editor. Vegetation and erosion: processes and environments. Wiley, New York, New York, USA.

Tolika, K., and P. Maheras. 2004. Spatial and temporal characteristics of wet spells in Greece. Theoretical and Applied Climatology 81:71-85.

Tsakiris, G., D. Tigkas, H. Vangelis, and D. Pangalou. 2007. Regional drought identification and assessment: case study in Crete. Pages 169-191 in G. Rossi, T. Vega, and B. Bonaccorso, editors. Methods and tools for drought analysis and management. Springer, New York, New York, USA.

Tsiourlis, G. M., P. Kasapidis, and P. Konstandinidis. 2001. The role of grazing on the maintain and degradation of Mediterranean ecosystems in central Crete, Greece. Pages 715-721 in K. Radoglou, editor. Proceedings of the International Conference on Forest Research: A Challenge for an Integrated European Approach, Volume II. 27 August-1 September 2001, Thessaloniki, Greece,

Tsiourlis, G., and P. Konstantinidis. 2006. Description of the vegetation structure and dynamics under climate and anthropogenic pressure: Part I. The Crete case study. National Agricultural Research Foundation (NAGREF) Forest Research Institute, DeSurvey Integrated Project, European Commission, Brussels, Belgium.

Turner, M. D., P. Hiernaux, and E. Schlecht. 2005. The distribution of grazing pressure in relation to vegetation resources in semi-arid West Africa: the role of herding. Ecosystems 8(6):668681.
Turner, M. D., and T. O. Williams. 2002. Livestock market dynamics and local vulnerabilities in the Sahel. World Development 30(4):683-705. 